\title{
Factors Affecting Loyalty Customer Services Banking Industry in East
} Java

\author{
Koesharijadi ${ }^{1}$ \\ ${ }^{1}$ Graduate Master Program Management, University Bina Darma Palembang, Indonesia \\ Correspondence: Priyono, Graduate Master Program Management, University Bina Darma Palembang, \\ Indonesia. Tel: 62-812-1697-4878. E-mail: priyono.unu_sidoarjo@yahoo.com
}

Received: February 18, 2016

Accepted: April 27, 2016

Online Published: May 22, 2016

doi:10.5539/ijbm.v11n6p168

URL: http://dx.doi.org/10.5539/ijbm.v11n6p168

\begin{abstract}
The purpose of this study was to determine the factors contained in the quality of services and how these factors influence the underlying between the formation of customer loyalty in the banking services industry.

This study is designed for internal and external customers banking is also seen as internal and external customer banking. Respondents of this research there are two types of internal respondents with a sample of 152 people and external respondents with a sample of 198 people, the number of total samples of 350 people in the banking industry in East Java. Data was collected through a questionnaire with statements that refer to Likert scale. Data analysis was performed using AMOS program.

The results showed that the image of the organization significantly influence customer expectations and customer value, organizational image does not affect the customer's satisfaction. Internal service quality significantly influence employee satisfaction and employee satisfaction significantly influence the quality of external services. External service quality effect on customer value. Customer expectations significantly influence the external service quality and value for the customer but the customer expectations significant negative effect on customer satisfaction. Value customers significant effect on customer satisfaction and customer loyalty. Customer satisfaction significantly influence customer loyalty.
\end{abstract}

Keywords: loyalty customer services, banking industry, East Java

\section{Introduction}

\subsection{Background}

An organization of course has the objective to be achieved, not least in terms of planning, improvement or improve service quality, organizational values, customer satisfaction, all of which will foster customer loyalty. Through an understanding of the concept of a service that it is believed, will provide the best chance to compete in creating and retaining customers. Hing, (1997); Meyer (1999) and Gilbert \& Parhizgari, (2000), based on the research results suggest that, an organization in providing good service to maintain subscriber (loyalty) have models, frameworks and performance practice called service profit chain. Service profit chain provides an argument that, there is a strong relationship between the quality of internal services, employee job satisfaction, employee loyalty, employee productivity, customer value of service, customer satisfaction and customer loyalty. Still there are many factors involved in the relationship between service quality and customer loyalty. Thwaites (1999), suggests that, in order to win a competition among companies, the attention of the most important related to facility planning services more quality, determining the location of the company, operational effectiveness, the image of the company, attention to the needs, desires or expectations of customers and the ability of Contact personnel to customers. Conlon, Matta, and Devaraj (2001), also stated that, customer satisfaction perceived service facilities relating to customer satisfaction and customer loyalty.

Citing what has been put forward by Meyer at al. (1999); Thwaites at al. (1999) and Conlon, Matta, and Devaraj at al. (2001), there are two (2) key issues related to customer loyalty. First, that the company's program in environmental competition is particularly keen business is how to grow and maintain the loyalty of existing customers. Secondly, there are many factors behind the emergence of customer loyalty that needs to be addressed by the company. Quality of service and customer loyalty will be generated by the company's operations performed well. But between them there is a relationship between (intermediate links) that consists of 
many factors (intervening) that still need to be better understood (Parasuraman, 1996). What is proposed by Parasuraman at al. (1996); Meyer at al. (1999); Thwaites at al. (1999) and Conlon, Matta and Devaraj at al. (2001), there is an interesting subject for further investigation. There are many factors that need to be studied and understood well that underlie the formation of service quality and customer loyalty.

As noted Olson and Dover in Zeithaml, Parasuraman and Berry (1993), the customer will choose the service provider after comparing the services they have rendered to the services previously expected.

Customer expectations for service quality will affect the customer satisfaction (Fornell, 1992). Customer satisfaction with a service is affected by customers' expectations of the services that will be received by the (Anderson et al., 1996). Image that the organization will take effect in two respects. First, the image will affect customer expectations for service quality will be accepted. Second, the image affects customer value. Zeithaml and Bitner (1996), adduce there are some things about that image, the image can sustain or overthrow consumer perception of value, quality, customer satisfaction and loyalty. The value of an image capable of affecting the value consumers (Kotler, 2000). Customer satisfaction is an evaluation after purchase (Engel, 1990). Satisfaction with a service affected by perceived value (Anderson, 1996). Satisfaction is the difference (discrepancy) between observed to be desired. Customer satisfaction resulting from the comparison between the performance of the services perceived by consumers to be expected (Poisz \& Van Grumbkow, 1988; Parker \& Mathews, 2001). Customer value after taking effect on the perceived satisfaction (Taylor \& Hunter, 2003).

Customer value can be affected by two (2) factors. First, the expectations of the customer service and secondly, the quality factor of external services, services actually received by customers. Services felt or enjoyed by these customers, will soon get a vote or are not in line with expectations or desires of customers (Kahn, Strong, \& Wang, 2002). Service quality can be measured by the difference between customer expectations with customer perception of the performance of these services (Grönroos, 1988; Owen \& Othman, 2002). Service quality involves a comparison (discrepancy) between the expectations of the customers with the services received by customers on the performance of the actual service (Parasuraman, 1988). Measuring the quality of services is by comparing the expected service or customer expectations of services that will be received by the perceived service or perceived service (Grönroos, 1994; Grönroos, 1998). Customer expectations about the quality of service desired affect service quality external service provider gives the customer. Quality of service is also a level of excellence of a product that their customers expect and control over the level of excellence it to the customer's wishes (Wykof in Lovelock, 1988). Customer expectations is positively related to the quality of services provided on an ongoing basis for the foreseeable future (Bitner \& Hubert, 1994; Oliver, 1980, 1997; Klein, Ganesan, \& Hess, 2003).

In order to achieve good quality of service, it is necessary to realize the management of employee satisfaction. That is, the realization of good quality services to the customers greatly influenced how much the management is able to realize the job satisfaction of employees. Job satisfaction is an attitude that is generally indicated by an employee to work, (Byars \& Rue, 2000). Wood (1998), job satisfaction is a positive or negative attitude of perceived employee to work. Job satisfaction can be realized if management is able to provide a good quality of internal services to employees.

\subsection{Formulation of the Problem}

1). Does the image of the organization (CTR PLG) significant positive effect on the customer expectations (HRP PLG).

2). What is the image of the organization (CTR PLG) significant positive effect on customer value (NL PLG).

3). Does the image of the organization (CTR PLG) significant positive effect on customer satisfaction (KPS PLG).

4). Is the quality of internal services (KL LYN INT) significant positive effect on employee satisfaction (KPS KRJ KYW).

5). Is the employee satisfaction (KPS KRJ KYW) significant positive effect on the quality of external services (KL LYN ext).

6). Is the customer expectations (HRP PLG) significant positive effect on the quality of external services (KL LYN ext).

7). Is the customer expectations (HRP PLG) significant positive effect on customer value (NL PLG).

8). Is the customer expectations (HRP PLG) positive significant effect on customer satisfaction (KPS PLG).

9). Is the quality of the external service (TOS LYN ext) significant positive effect on customer value (NL PLG). 
10). Does the customer value (NL PLG) significant positive effect on customer satisfaction (KPS PLG).

11). Is the customer (NL PLG) significant positive effect on customer loyalty (LY PLG).

12). Is the customer satisfaction (KPS PLG) significant positive effect on customer loyalty (LY PLG).

\section{Conceptual Framework and Research Hypotheses}

\subsection{Conceptual Framework}

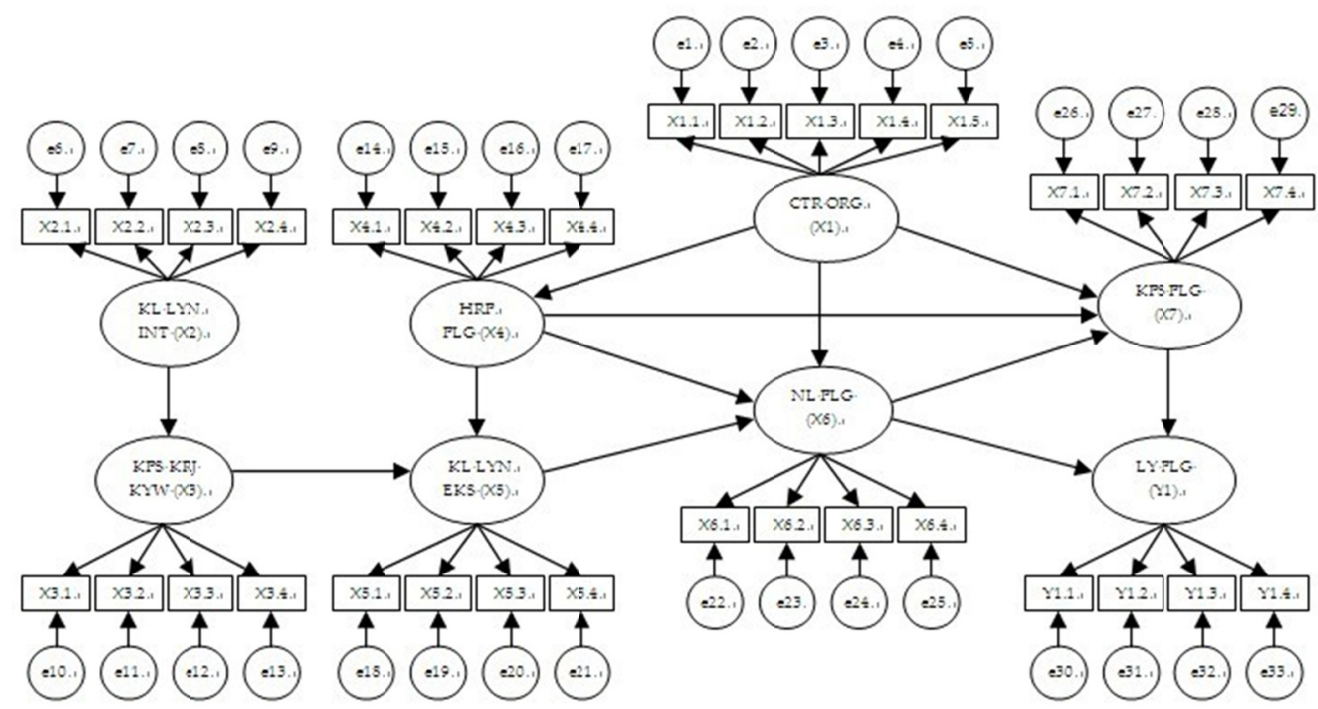

Figure 1. Framework research

\section{Research Methods}

\subsection{Object Research}

Objects in this study is a banking branch in East Java Province. The banks include State Bank, Bank Regional Government, National Private Banks, Foreign Banks and Mixed. When the study in November $2006 \mathrm{~s} / \mathrm{d}$ in January 2007.

\subsection{Data Collection Technique}

Data collector using the enclosed questionnaire. Score each item using a modified Likert scale.

\subsection{Sampling Technique}

The sampling technique Stratified Proportional Random Sampling, because the elements of the population / heterogeneous sample (different banks and customers due to differences in the characteristics of the region). The first step, taking the subjects from each district / city that is comparable to the number of subjects each work unit (Proportional Sampling). The second step, draw a sample in the group that are not overlapping.

\subsection{Data Analysis Technique}

Structural Equation Modelling (SEM) was used instead to produce a model, but to confirm a theoretical model that has been developed through empirical data. $\leq \rho$ ), were considered significant when $\rho$ ), the value of probability ( $\lambda$ Structural Equation Modelling (SEM) AMOS 5. Interpretation of the measurement results based on the significance level loading factor or coefficient lambda. 


\section{Results and Discussion}

\subsection{Research Result}

\subsubsection{Respondents}

Based on Table 1 and 2 above shows that all respondents in this study of 350 (three hundred and fifty) respondents. Internal Respondents 152 (one hundred and fifty-two) and external respondents 198 (one hundred and ninety eight) people.

Table 1. Respondents internal

\begin{tabular}{|c|c|c|c|}
\hline Item & Number of questionnaires sent & $\begin{array}{l}\text { Number of questionnaires } \\
\text { returned }\end{array}$ & Percent \\
\hline Kota Surabaya & 50 & 34 & 68 \\
\hline City Malang & 30 & 23 & 76 \\
\hline City Madiun & 20 & 16 & 80 \\
\hline City Jember & 20 & 13 & 65 \\
\hline City Pasuruan & 15 & 9 & 60 \\
\hline City Kediri & 20 & 15 & 75 \\
\hline District Malang & 15 & 12 & 80 \\
\hline District Jombang & 15 & 9 & 60 \\
\hline District Gresik & 15 & 9 & 60 \\
\hline District Magetan & 15 & 12 & 80 \\
\hline Amount & 215 & 152 & 71 \\
\hline
\end{tabular}

Sources: Primary data processed.

Table 2. Respondents external

\begin{tabular}{llll}
\hline Item & Number of questionnaires sent & Number of questionnaires returned & Percent \\
\hline Kota Surabaya & 50 & 30 & 60 \\
City Malang & 40 & 26 & 65 \\
City Madiun & 40 & 22 & 55 \\
City Jember & 40 & 18 & 45 \\
City Pasuruan & 25 & 16 & 64 \\
City Kediri & 40 & 21 & 53 \\
District Malang & 25 & 15 & 60 \\
District Jombang & 25 & 17 & 68 \\
District Gresik & 25 & 15 & 60 \\
District Magetan & 25 & 18 & 72 \\
Amount & 215 & 198 & 60 \\
\hline
\end{tabular}

Sources: Primary data processed.

\subsubsection{Validity and Reliability}

Examination of the validity of instruments with intercorrelation test, if the probability value $\mathrm{r}<0.05$ item in question is valid. Validity in Structural Equation Modelling (SEM) were used in this study is the convergent validity, namely the suitability of the model with the data assessed from measurement model developed to determine whether each indicator is estimated validly able to measure the variables of the concepts tested. Instrument reliability test to see Cronbach $\alpha$ coefficient> 0.6. Reliability is a measurement of internal consistency of the indicators a constructs which indicates the degree of suitability of each indicator that identifies something to get a reliable measure. Based on the results of the validity and reliability of all variables of this study, valid and reliable, it can be seen from the probability value $r<0.05$ and Cronbach $\alpha$ coefficient $>0.6$.

4.1.3 Examination of the Assumptions Underlying the Structural Equation Modeling (SEM)

\subsubsection{The Assumption of Normality in the Data}

Referring to the SEM column test c.r final model (Assessment of normality), if the column contained c.r score> $2: 58$ or $<-2.58$ (normality of the distribution of alpha $1 \%$ ) proved to be the data distribution is not normal. 
Conversely if c.r $<2: 58$ or $>-2: 58$ normal distribution of data. Basically, the assumption of normality for the SEM is not too critical when $\geq 100$ observation data, as based on Central Limit Theorem (Central Limit Theorem) can be produced from a large sample sample statistic approaches a normal distribution (Solimun, 2002). This study uses 350 observational data, the data is assumed to be normal.

\subsubsection{Evaluation Univariate and Multivariate Outliers}

Based on cases (observations) that has a value z-score of 3.0 is categorized as outliers, for large samples over 80 observation, evaluation guideline threshold value z-score range of 3 to 4 (Hair, 1995 in Augusty, 2005). This study considered a large sample (350 respondents), above 80 observations, then the outliers occur if the z-score of 4.0; based on descriptive statistics tables the standardization all values in the z-score has an average value equal to zero with a standard deviation of one (Augusty, 2005). This research data freely univariate outliers, because there are no variables that have $\mathrm{z}$-score above the limit figure.

Case multivariate outliers occur if the value is greater than the distance mahalanobis Chi-square value calculated (Augusty, 2005). Based on the value of Chi square at 41 degrees of freedom (the number of variables) at a rate of 0.01 siginificance or X2 $(41,0.01)=74745$ (Gujarati, 1997). From calculations using AMOS obtained mahalanobis distance-squared value of at least 38.097 and 74.246 maximum value, it can be concluded there are no multivariate ouliers. $\chi$ To determine a case (various answers of the respondents) gave rise to a multivariate outlier, is to calculate the value limits based on the value of Chi-square degrees of freedom of the number of variables at the 0.01 level or

\subsubsection{Confirmatory Factor Analysis (CFA)}

required $\geq 0.40$, meaning that the variable is not the same dimensions $\lambda$ CFA measurement model is a modeling process to investigate their un dimensionality of indicators that describe a factor or latent variables. Lambda value with other variables to explain a latent variable. Test weights of factors determine the strength of the dimensions that make up the latent factors, seen scores critical ratio greater than 2.0 indicates that it constitutes a significant variable dimension of the latent factors are formed.

SEM analysis results for the final stage of measurement and test results factor model of the relationship between variables.

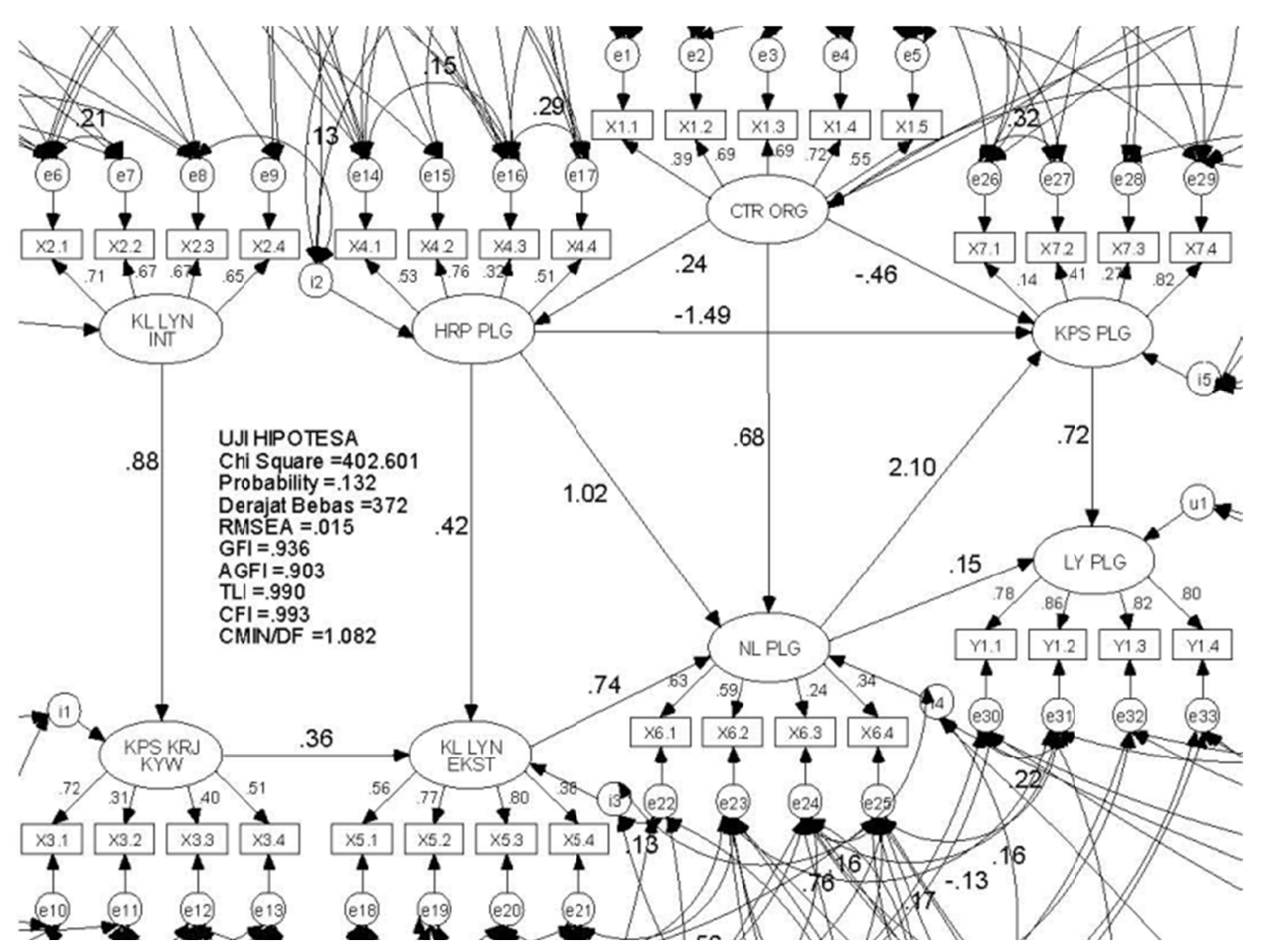


The result of the final model presented in the figure above, and evaluated based on the goodness of fit indices with the criteria of the model as well as critical values that have compatibility data.

Based on the evaluation of the model show that the evaluation of the model's response to constructs whole variety of criteria already meet the required criteria, so that the model can be said to be not critical violations. The model put forward relatively acceptable or have compatibility with the data.

\subsection{Hypothesis Testing Results and Discussion}

Testing the hypothesis with regard to the outcome of the structural model SEM, can be described as follows below.

1). There is a significant positive effect between the image of the organization towards the customer's expectations. The findings of this study further support findings and Larry Gulledge, (1988); Naumann, giel and Caelan (1994) and Heung, (1996). The results of this study indicate 3 (three) things why the bank's image affect the customer's expectations. First, customers choose a bank that has a good image in the hope of getting a better service. Second, in an effort to minimize the risks that may be encountered mainly related to the service and security of funds invested, customers tend to choose a bank that has a good image. Third, the image is formed of observation, experience and variety of information that has been obtained previously.

2). There is a significant positive effect between the image of the organization towards customer value. The findings of this study further supports the findings of Smith, Andrews, and Blevins (1992); Conlon, Matta, and Devaraj (2001) and Parasuraman, Zeithaml and Bitner (1996). The better the quality of service, the image that is also getting better, meaning that customers increasingly high ratings because it is associated with the image and the service is getting better or vice versa. After getting customer service immediately assess and will be associated with the image that has been obtained previously. There are two (2) terms of why the image affects customer value. First, the image is a function of the evaluation (score) the consumer of the service. Second, the image obtained by consumers before (saved in memory) can sustain and undermine the value of consumers towards quality.

1). There is no significant influence between the image of the organization toward customer satisfaction. The findings of this study do not support or contrary to the results of the previous research conducted by Conlon, Matta and Devaraj, 2001; Zeithaml and Bitner, 1996 and Selnes, 1993; Athanassopoulus, 2000) who said the Organization's influential image against consumer satisfaction towards the services provided. These findings turned out to be contradictory because it is caused by two things. First, customers tend to choose banking that has a good image in order to obtain a satisfactory service. Secondly, but not necessarily banking with a good image is always able to provide a satisfactory customer service, such as the customer experience often still a long queue, still existence of parking fees and banking security surroundings that have yet to fully guarantee the security of the customer themselves. The second condition is this gap that frequently occurs.

2). There is a significant positive influence between the internal organization of service quality towards job satisfaction of employees. The results of this research increasingly supports the results of the previous research conducted by Prabhu, (1996); Gilbert and Parhizgari, (2000). The supporting factors of job satisfaction of the employee's salary and wages, systems administration, job security and the chance of promotion and development Internal service quality affects job satisfaction (Prabhu, 1998). The quality of internal services to employees is the first factor as a supporter of the formation of customer loyalty in the long term (Gilbert \& Parhizgari, 2000). This condition indicates that a conducive working environment that is shown by the mastery job well and work tools, support good relations between employees and a good workplace design, is the Organization's internal service quality affects job satisfaction of employees. Quality internal service quality are expected to provide the satisfaction of employees in the works, which will affect attitudes and behavior related to his job. Employees are the ones who are in firms that have objective and motivation in work as well as having the influence of performance against the work. Job satisfaction is a feeling about what employees obtained or received or perceived in the work related to motivation or desires.

3). There is a significant positive influence on job satisfaction among employees to quality external services. The results of this research increasingly supports the results of the previous research conducted by Prabhu (1996); Gilbert and Parhizgari (2000); Conduit and Justin (2002). They assert that employee satisfaction, influence on external service quality is good. Employees who feel satisfied in the works will affect their performance towards the better. Attitudes and their behavior in work will also be associated with the service that they provide to external customers. There are 2 (two) things of concern. First, the factors of job satisfaction is determined by salary, systems administration, security and systems work, education (training) and the chance of promotion. Second, employees are the ones who are in firms that have objective and motivation in work. Third, the two 
things have performance against the work. So is the feeling of job satisfaction of the employees about what is gained (accepted) in the works that deal with motivation (desires) that affect behavior and attitude toward her work

4). There is a significant positive influence between customer expectations with the quality of external services. The results of this research increasingly supports the results of the previous research conducted by Thwaites, (1999). Quality should be at the start of the needs and expectations of customers and end in customer perception (Kotler, 2000). Quality emphasized orientation on the fulfillment of customer expectations (Joseph, 2002). Quality of service indicated relate positively with customer expectations on an ongoing basis for the foreseeable future (Klein, Ganesan, \& Hess, 2003). Customer satisfaction and customer expectations is a target that is always changing in accordance with development needs, so that required the presence of a clearer picture of what customers need and like what it really is. Understanding of customer expectations is a prerequisite for improving the quality and to achieve total satisfaction for customers. Quality of service indicated the Organization dealing positively with customer expectations on an ongoing basis (continuity) in the long term and this will affect the quality of service of the response or responses to customers to meet again in my next purchase. Psychologically, a consumer to effectively respond in assessing performance shown by the entire organization, with the hope of the existence of an improvement in the service, as customer satisfaction is a function of the service consumer to meet back up with quality expectations and the performance of the new and improved (Oliver, 1980; Bitner \& Hubbert, 1994; In 1997, Oliver Klein, Ganesan \& Hess Jr, 2003). The customer when doing transaction has some expectations regarding the transaction will be done. Banking as a service industry need to know what is the hope of the customer because of the customer's expectations of quality determine the direction to be given next. Customer identification needs to be done correctly. Maintain the viability and have a chance to develop in a sustainable way, banking should be able to produce and provide products and services that generate, it soon got the assessment of clients, therefore banking should be able to make what is needed based on what the customer expectations. These findings indicate two things. First, the quality of service emphasizing the orientation on the fulfillment of customer expectations. Second, it required a clear picture about what is and what kind of expectations that actual customers. Customer expectations of service focused in three (3) things, namely, better, cheaper and faster. Banking customer wish free of all administrative costs, vehicle parking fees when the bank, get a friendly and courteous service and hope to have a quick and precise service. What is expected of the customer is within a system of banking services.

5). There is a significant positive influence between customer expectations of customers. The results of this research increasingly supports the results of the previous research conducted by Patterson and Spreng, (1997); Thwaites (1999); Dongkeun (2000); Kandampully and Suhartanto (2000). Compare between what clients into his expectations before making the purchase reunited with the actual customer service received expressed or not in accordance with what was to become the expectation. These findings indicate that a client doing a comparison (discrepancy) between hope (expectation) and quality of service that has been received or for performance (performance) from the actual service.

6). There is a significant negative influence between customer expectations towards customer satisfaction. The findings of this research result is inversely proportional to the research findings, Fornell (1992); Anderson (1996); Kandampully and Suhartanto (2000); Hess, Ganesan, and Justin, (2003), stating that the customer's expectations towards the quality of service affect customer satisfaction. Why this finding is inversely proportional to the findings of previous research, there are a couple of reasons. First, customer expectations related to desire an inexpensive cost. Second, is banking that prioritizes profit oriented. Third, the second of the above because there is a gap. This gap means that the higher the customer what to expect especially associated with the hopes of getting a cheap stay, then banking increasingly difficult to meet the customer's expectations of what became of them.

7). There is a significant positive influence between the quality of the external service of the customers. The results of this research increasingly supports the results of the previous research conducted by Gronroos (1994); Parasuraman (1994); Andreassen and Lindestad (1997); Patterson and Spreng (1997); Mulyadi (1998); Thwaites, (1999); Kandampully and Suhartanto, (2000); Keeps and Durden (2001); Barness (2003). The findings of this study indicate that the quality of service that consists of the dimensions of the tangibles, policy, and outcomes have implications for interaction of the customer. So the customer perform the measurement of the quality of service by doing a comparison (discrepancy) between hope (expectation) previously with the quality of the services that have been received or for performance from the actual service. The quality of the external service is a service provided by banking to its customers. The quality of these services may take the form of physical and non physical. The quality of service that has been provided will be evaluated for this customer. Assessment of 
the quality of customer service has been given such compared to the service that is expected to declare a satisfied or not satisfied. So the measurement of the quality of the services that have been put forth, involves a comparison (discrepancy) between hope (expectation) of previous clients with quality services that have been received or which the customer has been enjoyed over performance from the actual service.

8). There is a significant positive influence between the value of the customers towards customer satisfaction. The results of this research increasingly supports the results of the previous research conducted by Engel, (1990); Gronroos, (1994); Kandampully and Suhartanto (2000); Levesque (2000); Durden (2001); Zins (2001); Taylor and Hunter (2003); Khatibi (2004). These findings indicate that the value of customers who have done against what was expected compared to the fact that there are, do customers to declare a satisfied or not satisfied. These findings also support the paradigm of customer value. In the paradigm of customer value focuses the company must all resources belonging to generate a value for customer satisfaction, so that in every stage of the process and any form of service activities should be aimed at producing a more value for customers. The value of customers who have done against what a chill compared to the reality, it is performed to reveal the customer satisfied or not satisfied. If that be the expectation that the majority can be met, it's what makes the customer feel satisfied. Banking has had a wide range of supporting facilities good service, the machine count money, ATM fees, free delivery and money transfer money fast and precise as a proponent of good service. The higher the quality of a service provided to customers, then growing satisfied customers who can be met by the service. Customers will be more satisfied if the services rendered are increasingly valued for her (relative to what has been previously thought). In business, competition environment where customers in control business, then this value should be customer paradigm focuses all resources belonging to generate a value for customer satisfaction, so that in each stage of the process and any form of service activities should be aimed at producing a more value for customers. A successful service management process is a process that is able to produce a satisfied customer.

9). There is a significant positive influence between the value of the customer against the customer loyalty. The results of this research increasingly supports the results of the previous research conducted by the Dean, (2002); Sobol, Singh, and Sirdeshmukh (2002); Saurina and Coenders (2003). Customer satisfaction resulting from the process of comparison (discrepancy) between the customer's perceived service compared to what was expected. Customer rating (discrepancy) have contribution in formation of complacency for the customers. The findings of this study in accordance with the disconfirmation paradigm (positive). Disconfirmation (positive) results in satisfaction. The assessment of this banking customers of the quality of service that can be fulfilled in receive or may be much (above) what is willed. This will foster outstanding trust to banking that can deliver more value than what previous customers estimated. The estimated results of this customer information obtained from friends, family and the ad or from the experience of past customers, but in fact the received service much better than what is gained on the basis of that information.

10). There is a significant positive influence between customer satisfaction toward customer loyalty. The results of this research increasingly supports the results of the previous research conducted by Woodside, Frey and Daili, (1989); Gronroos (1994); Spreng (1997); Thorpe (2000); Levesque (2000); Kandampully and Suhartanto (2000); Conlon, Matta and Devaraj (2001); Sobol, Singh, and Sirdeshmukh (2002); Fornell (1992); Taylor and Hanter (2003); Coenders (2003). The results of this study indicate the 5 (five) things due to the realization of customer satisfaction toward customer loyalty. First, customer satisfaction is a requirement for the formation of loyalty. Second, the level of satisfaction will heighten the recollection customers against the company. Third, the level of satisfaction will increase the positive information to the customer verbally. Fourth, satisfaction increases purchases. Fifth, improve satisfaction and behavior tendencies. The performance of banking as a good provider as the Foundation of customer service quality assessment has been given. If a customer perceives the quality of services in received exceeds the needs, wants and expectations then satisfaction perceived can be said to be high (positive disconfirmation) towards loyalty. Another possibility, if the assessment of the quality of service that clients in receipt of lower or do not meet the needs, wants and expectations then satisfaction customer banking can be said to be low or not satisfied, disappointment which give rise to complaints. Key in reaching customer loyalty is a positive disconfirmation.

11). The results of this research are the most fundamental is found empirical evidence that quality of service and loyalty relationship is not directly (simple). Between the two there is a relationship between the (intermediate links) in the form of variable interrupt (intervening variable) between the quality of the services provided by customer loyalty. These findings are at once provide proof over the existence of several factors (independent and intervening variable) that affect the formation of customer loyalty. Customer loyalty it gives a clear picture that a measure of loyalty refers to three (3) things as follows:

1). Consumer Interest in a product or service. 
2). The vulnerability of consumers to switch to another product or service.

3). Increase the tendency of a fun attitude and minimize the tendency of unpleasant attitude shown towards the service provider customers.

\section{Conclusions and Suggestions}

\subsection{Conclusion}

Based on the deliberations and results of hypothesis testing in the previous chapter, then a conclusion can be made as follows:

1). Banking belongs to the service industry and is one of the drivers of the dynamist economy of the country, then banking should be able to earn the trust of society as the owner and user of funds of funds. To gain the trust of that banking should be able to realize the quality of service that is best for the community as its customers. In giving satisfaction to customers to foster loyalty in service industry especially banking, quality of service is very important well managed.

2). The image is a common perception about a phenomenon or an impression against an object. Image owned by banking is determined by how large the bank acquired the confidence of the community as clients. In an effort to minimize the risk of facing, customers tend to prefer buying from service providers who have a good image in hopes of getting a better service, rather than the service provider with the image. Customer service compare between the received image of banking that has been gained from experience and from various information obtained previously. The image of the organization proved to be significant positive effect against customer expectations and customer value, but proved to have no effect significant positive towards customer satisfaction.

3). internal Service Quality is a manifestation of the Organization's services provided to its employees as internal customers of the Organization and the quality of service it is the internal factors first as a supporter of the formation of customer loyalty in the long term. Banking management must realize the quality of internal services to employees through the creation of a conducive working environment. This affects employee satisfaction in work. Based on a test of the hypothesis stated that the quality of internal services proved positive effect significantly to job satisfaction of employees.

4). Job satisfaction is a feeling about what employees obtained or received or perceived in the work related to motivation or desires. Employee job satisfaction is determined by salaries, bonuses and benefits, education, training, training and participation of employees in the taking of decision. Job satisfaction the significant positive effect to the quality of the external service. Employees who feel satisfied in work tends to produce better performance. The attitude and behavior of employees in work will be associated with the services provided to external customers. So a good external service quality is affected by how big the perceived satisfaction of employees in work.

5). Quality should start from the needs and expectations of customers and end on customer perception about the quality of it. Customer expectations is an estimate or confidence customers about what will be accepted. This banking customers expectations related to her desire of getting the cost is cheap and good service such as hospitality, courtesy, speed and accuracy. Customer expectations of significant positive effect on quality of service and value for external customers. This indicates that before making a purchase customers have some hopes about the service and the fees they want. This customer expectation will be compared with the services received or compared to the actual events. Customer satisfaction and customer expectations is a target which always varies in accordance with the development needs of the customer, so that required the presence of a clearer picture about what is and what needs customers who were the actual expectations. But the hypothesis further proves that the negative effect this customer expectation significantly to customer satisfaction. This is taken to mean that the higher what is expected of the customer associated with the good service and cost-efficient (cheap), then banking is increasingly difficult to meet what the expectations of the customers. Banking is a business entity that prioritizes profit oriented.

6). External service quality Factors consist of physical quality (tangibles) form look and cleanliness of public infrastructure and convenience is offered to customers with layout (location). Convenience of location to reach (accessibility), a much-needed banking clients. Quality policy (policy) shows on aspects of the quality of services that are directly influenced by the various policies of the service providers, such as hours of operation and good credit policy. The quality of interaction (interaction) shows about customer perception as to whether they feel there is a customer of intimidation, pressure or they feel uncomfortable in interact. 


\subsection{Advice}

At the end of the next subjects put forward some suggestions as follows:

1). in an era of competitive banking competition need to optimize resources that belong to attract new consumers or at least be able to maintain existing customers before. There are several factors that need to be observed to obtain banking loyalty from its customers or attract new customers.

a. delivering superior services that allow a pleasant behavior can increase and decrease the unpleasant behavior.

b. need to know how big the quality of service which is enough to maintain the existing consumers or to attract new consumers, then the introduction of the customer more in depth needs to be done.

c. Loyalty Program starts from focusing attention on internal business processes and learning, including management (learning and growth) for the sake of gaining customer loyalty associated with financial results that enable long-term organizational development.

d. quality of services both realized through shared responsibility in each individual that exists within the Organization to provide the best service for customer satisfaction.

2). maximum permissible muster Banking funds as many of the community, but not only based on mutual benefit and less attention on mutual respect. Mutual benefit from the banking, marked by "chasing" or hold funds from the public in large numbers, but the system of banking services that are less able to respond to the wishes and complaints of customers and on the other side of the inability of the bank in realizing the quality of service to the customer is good and satisfactory. Then we recommend banking must be able to regenerate the confidence to its customers about the services provided are the best, the introduction of the customer need to do this he knows expectations will be associated with the customer. There are a few things that need to be done in banking to know or find out what the customer wants and this is done to reduce or minimize customer complaints, among others:

a. Optimize system suggestions

b. Form (streamline) return the complaint handling or customer dissatisfaction

c. setting back work system especially the customer service if the client queue often occur a long

d. situation analysis through circumstantial observations.

3). As a service industry, banking need to develop human resources that belong to the better direction, then banking management must be able to manage professionally with a wide range of support facilities are adequate to support the function of good service for customer satisfaction.

4). Based on the research results that have been obtained as well as the various limitations that exist in this research, then put forward some suggestions for upcoming research in developing knowledge in the field of marketing services in particular banking services.

a. the coming Research can perform grouping of banking industry based on type or based on ownership of banking to know the type of banking ownership or which one has the best quality of service.

b. Research to come can also increase the number of variables. This needs to be done because consumer behavior in purchasing a recurring (loyalty) is influenced by many factors which have not been examined in this study, be it either a mediator or intervening variables to another. The addition of variables and indicators or samples in the hope of getting a better research results.

c. research that will come are expected to be able to use other methods of analysis, as do different test against each type of banking. So the result later can be compared to the results of this research, specifically to examine the factors that influence the attainment of good quality services that are able to foster customer loyalty.

d. the results of this study suggest that the relationship between service quality and customer loyalty is not straightforward or simple. But between them there is a relationship between the (intermediate links) be intervening variable that needs to be well understood by subsequent research. There are still many intervening variable between quality of service and customer loyalty that is outside of this research study.

5). The study in measuring the quality of external service refers to items that exist on the servqual expressed Parasuraman, (1995) and combined with the existing items on the stated servperf by Cronin and Taylor, (1992). Upcoming research need to do adaptations of dimensions, sub dimensions and items that exist on the and further to be able to unban. 


\section{References}

Albert, C. (2002). Service Loyalty the Effects of Service Quality and the Mediating Role of Customer Satisfaction. European Journal of $\quad$ Marketing, $\quad 36(7 / 8), \quad$ 811-828. http://dx.doi.org/10.1108/03090560210430818

Alford, B. L., \& Engelland, B. T. (2000). Advertised Reference Price Effects on Consumer Price Estimates, Value Perception, and Search Intention. Journal of Business Research, 48, 93-100. http://dx.doi.org/10.1016/S0148-2963(98)00095-2

Andreassen, T. W., \& Lindestad, B. (1998). Customer Loyalty and Complex Service. International Journal of Service Industry Management, 9, 7-23. http://dx.doi.org/10.1108/09564239810199923

Andrew, F., Anne, S., \& Geoffrey, D. (2001). Service Quality Enhancement: The Role of Employees' Service Behaviours. Aston Business School Research Institute, Aston University, Birmingham B4 7ET.

Armstrong, G., \& Kotler, P. (1996). Principles of Marketing (7th ed.). Prentice Hall. Inc.

Athanassopoulos, A. D. (2000). Customer Satisfaction Cues to Support Market Segmentation and Explain Switching Behavior. Journal of Business Research, 47, 191-207. http://dx.doi.org/10.1016/S0148-2963(98)00060-5

Barnes, G. J. (2003). Secrets of Customer Relationship Management. Andi, Yogyakarta.

Bernhardt, K. L., Donthu. N., \& Kennett, P. A. (2000). A Longitudinal Analysis of Satisfaction and Profitability. Journal of Business Research, 47, 161-171. http://dx.doi.org/10.1016/S0148-2963(98)00042-3

Bolton, R. N., \& Drew, J. H. (1991). A Multistage Model of Customers Assessment of Service Quality and Value. Journal of Customer Research, 54, 64-82. http://dx.doi.org/10.1086/208564

Bowen, J., \& Shoemaker, S. (1998). Loyalty: A Strategic Commitment. Cornell, H. R. A. Quarterly, $2,12-25$. http://dx.doi.org/10.1177/001088049803900104

Brady, M. K., \& Christopher, J. R. (2001). Searching for a Concensus on the antecedent role of Service Quality and Satisfaction: An Exploratory Cross National Study. Journal of Business Research, 51, 53-60. http://dx.doi.org/10.1016/S0148-2963(99)00041-7

Brady, M. K., \& Joseph, C. J. (2001). Some Thoughts on Conceptualizing Perceived Service Quality: A Hierarchical Approach. Journal of Marketing, 65, 34-49. http://dx.doi.org/10.1509/jmkg.65.3.34.18334

Brochner. J. (2000). Understanding Service Qualities in Facilities Management: A Transaction Cost Approach. International Symposium on Facilities Management and Maintenance, 455-459.

Butcher, K., Sparks, B., \& O’Callaghan, F. (2001). Evaluation and Relational Influences on Service Industry Management, 4, 310-327. http://dx.doi.org/10.1108/09564230110405253

Byars, L. L., \& Rue, L. W. (2000). Human resources Management (6th ed.). Mc Graw Hill.

Callan, R. J. (1994). Development of a Framework for the Determination of Attributes Used for Hotel Selection-Indication from Focus Group and in-depth Review. Hospitality Research Journal, 18, 53-74.

Carman, J. M. (1990). Consumer Perceptions of Service Quality: An Assessment of the SERVQUAL Dimension. Journal of Retailing, 66(1), 23-33.

Coenders, G., \& Saurina, C. (2002). Predicting Overall Service Quality. A Structural Equation Modelling Approach, Developments in Social Science Methodology Anuska Ferligoj and Andrej (Editors). Metodoloski Zvezki, 18, 217-238.

Conlon, E., Matta, K., \& Devaraj, S. (2001). Product and Service: The Antecedents of Customer Loyaly in the Automotive Industry. Production and Operations Management, 10(4), 424-439.

Coyne, K. P. (1989). Beyond Service Fads: Meaning Strategies for the Real World. Sloan Management Review, 7-27.

Cronin Jr, J. J., \& Steven, A. T. (1992). Measuring Service Quality: A Reexamination and Extention. Journal of Marketing, 56, 55-68. http://dx.doi.org/10.2307/1252296

Cronin Jr, J. J., \& Steven, A. T. (1994). SERVPERF Versus SERVQUAL: Reconciling Performance-Based and Perception-Minus-Expectations Measurement of Service Quality. Journal of Marketing, 58, $125-131$. http://dx.doi.org/10.2307/1252256

Cronin Jr, J. J., Brady, M. K., \& Hul, G. T. (2000). Assessing the Effect of Quality, Value and Customer 
Satisfaction on Customer Behavior Intention in Service Enveronments. Journal of Retailing, 76(2), 193-218. http://dx.doi.org/10.1016/S0022-4359(00)00028-2

Cronin Jr, J. J., Brady, M. K., Richard, R. B., Roscoe, H. Jr., \& Donald, J. S. (1997). A Cross-sectional Test of the Effect and Conceptualization of Service Value. The Journal of Service Marketing, 11(6), 373-391. http://dx.doi.org/10.1108/08876049710187482

Dabholkar, P. A., Shepherd, C. D., \& Thorpe, D. I. (2000). A Comprehensive Framework for Service Quality: An Investigation of Critical Conceptual and Measurement Issues Through a Longitudinal Study. Journal of Retailing, 76(2), 139-173. http://dx.doi.org/10.1016/S0022-4359(00)00029-4

Dabholkar, P. A., Thorpe, D. I., \& Joseph, O. R. (1996). A Measure of Service Quality for Retail Stores: Scala Development and Validation. Journal of Academy of Marketing Science, 24(1), 3-16. http://dx.doi.org/10.1007/BF02893933

Dahaner, P. J. (1995). Research in Customer Satisfaction; Methodological and Measurement Isseus. New Zealand Journal of Business, 17(2), 33-45.

Dahaner, P. J., \& Matteson, J. (1994). Customer Satisfaction During the Service Dalivery Proces. European Journal of Marketing, 28(5), 5-16. http://dx.doi.org/10.1108/03090569410062005

Dean, M. A. (2002). Perspectives Service Quality in Call Centres: Implications for Customer Loyalty. Managing Service Quality, 12(6), 414-423. http://dx.doi.org/10.1108/09604520210451894

Dhammesta, B. S. (1999). Customer Loyalty: A Study of Conceptual As Researcher Guide. Journal of Economics and Business Indonesia, 4(3), 73-88.

Dharma, A. (1991). Job Performance Management Practical Guidelines for Supervisor to Improve Job Performance. Rajawali, Jakarta.

Disney. J. (1999). Customer satisfaction and Loyalty: The Critical Elements of Service Quality. Total Quality Management \& Business Excellence, 10(4\&5), 491. http://dx.doi.org/10.1080/0954412997442

Ditcher, R. (1991). What's in on Image. Journal of Consumer Marketing, 2, 75-81.

Echtner, C. M., \& Ritchie, B. J. R. (1991). The Meaning and Measurement of Destination Image. The Journal of Tourism Studies, 2, 2-12.

Engel J. F. (1990). Consumer Behavior (6th ed.). Chicago: The Dryden Press.

Engel J. F., Roger, D. B., \& Paul, W. M. (1994). Consumer Behavior. Jilid 1, Binarupa Aksara, Jakarta.

Fornell. C. (1992). A National Customer Satisfaction Barometer: The Swedish Experience. Journal of Marketing, 56(January), 12. http://dx.doi.org/10.2307/1252129

Gaspersz, V. (2002). Total Quality Management. Gramedia Pustaka Utama, Jakarta.

Gilbert, R. G., \& Parhizgari, M. A. (2000). Techniques Organizational Effectiveness to Support Service Quality. Managing Service Quality, 10(1), 46-51. http://dx.doi.org/10.1108/09604520010307030

Grapentine. T. (1998). The History and Future of Service Quality Assessment, Connecting Customer Needs and Expectations to Business Processes, In recognition of the $10^{\text {th }}$ anniversary of the publication of the SERVQUAL scala in the Journal of Retailing, the Academy of Marketing Science sponsored a special session on the advancements in service quality assessment over the last decade.

Gremler, D. D., \& Brown, S. W. (1997). Service Loyalty; its Nature, Importance and Implications. Advancing Service Quality: A Global Perspective. In Edvardsson et al. (Eds.), Quiz 5. Conference Processing (pp. 171-181). University of Karlstad, Sweden,

Gronross, C. (1983). Strategic Management an Marketing in the Service Sector. Cambridge: Mssachu Setts.

Gronross, C. (1998). Marketing Service: The Case of Missing Product. Journal of Business \& Industrial Marketing, 13(4/5). http://dx.doi.org/10.1108/08858629810226645

Hallowell, R. (1996). The Relationship of Customer Satisfaction, Customer Loyalty and Profitability: An Empirical Study. International Journal of Service Industry Management, 7, 27-42. http://dx.doi.org/10.1108/09564239610129931

Handoko, T. H. (1998). Management. BPFE, Universitas Gajah Mada, Jogjakarta.

Heung, V. C. S., Mole, C., Kwan, A. (1996). Brand Loyalty in Hotels: An Exploratory Study of Overseas Visitors to Hongkong. Australian Journal of Hospitality Management, 1, 1-11. 
Jacques, I., \& Patrice, R. (1999). A Study of the Relationships between Compensation Package, Work Motivation and Job Satisfaction. Journal of Organizational Behavior, 20, 1003-1025. http://dx.doi.org/10.1002/(SICI)1099-1379(199912)20:7<1003::AID-JOB941>3.0.CO;2-K

Johnston, R. (1995). The Determinant of Service Quality: Satisfiers and Dissatisfier. International Journal of Service and Management, 6(5), 53-71. http://dx.doi.org/10.1108/09564239510101536

Kahn B. K., Strong, D. M., \& Wang, R. Y. (2002). Information Quality Benchmarks: Product and Service Performance. Communications of the ACM, 45(4), 184-192. http://dx.doi.org/10.1145/505248.506007

Kamakura, A. W., \& Mittal, V. (2000). Satisfaction, Repurchase Intention and Repurchase Behavior: Investigating the Moderating Effect of Customer Characteristics. Journal of Marketing Research, 38, 131-142.

Kandampully, J. (1998). Service Quality to Service Loyalty: A Relationship Which Goes Beyond Customer Service. Total Quality Management \& Business Excellence, 9(6), 431-443. http://dx.doi.org/10.1080/0954412988370

Kandampully, J., \& Suhartanto, D. (2000). Customer Loyalty in the Hotel Industry: The Role of Customer Satisfaction and Image. International Journal of Contemporary Hospitality Management, 12(6), 346-351. http://dx.doi.org/10.1108/09596110010342559

Khatibi, A., \& Ismail, H. (2004). Study of the Relationship between Perception of Value and Price and Customer Satisfaction. Journal of American Academy of Business, 4, 309-313.

Klein, N. M., Ganesan, S., \& Hess, Jr. R. L. (2003). Service Failure and Recovery: The Impact of Relationship Factors on Customer Satisfaction. Academy of Marketing Science Journal, 31(2), 127-145. http://dx.doi.org/10.1177/0092070302250898

Kotler, P. (1997). Marketing Management: Analysis, Planning, Implementation, and Control (9th ed.). Prentice Hall Inc, Englewood Cliffs, New Jersey.

Kotler, P. (2000). Marketing Management, the millennium. Upper Saddle River, NJ: Prentice-Hall, Inc.

Larry, G., \& Gulledge. (1988). Measure Satisfaction Performance to Meet Customers Expectat. Marketing News, 22(6), 34-35.

Larry, J. W., \& John, T. H. (1998). Antecedents and Consequences of Satisfaction and Comitment in Turnover Models: A Reanalysis Using Latent Variable Structural Equation Methods. Journal of Applied Psychology, 71(2), 219-231.

Lee, H., Lee, Y., \& Yoo, D. (2000). The Determinants of perceived Service Quality and its Relationship with Satisfaction. Journal of Service Marketing, 14(3), 217-231. http://dx.doi.org/10.1108/08876040010327220

Lockheed, M. E., \& Eric, H. (1987). Improving the Efficiency of Education in Developing Countries: Review of the Evidence. World Bank.

Lovelock, C. (1988). Managing Services, Operations \& Human Resources. London: Prentice Hall International, Inc.

Luthans, F. (1998). Organizational Behavior (9th ed.). New York: Mc Graw-Hill, Inc.

Maclaran, P., \& Pauric, M. (1999). Managing Service Quality for Competitive Advantage in Small Engineering Firms. International Journal of Entrepreneurial Behavior \& Research, 5(2), 35-47. http://dx.doi.org/10.1108/13552559910274480

Mazanec, J. A. (1995). Positioning Analysis with Silf-Organising Maps; An Exploratory Study on Luxury Hotels. The Cornul H. R. A Quanterly, 12, 80-92.

Meyer, A., Chase, R., Roth, A., Voss, C., Sperl, U. K., Menor, L., \& Blackmon, K. (1999). Service Competitiveness: An International Benchmarking Comparison of Service Practice and Performance in Germany, UK and USA. International Journal of Service Industry Management, 10(4), 369-379. http://dx.doi.org/10.1108/09564239910282334

Milbourn, G. Jr., \& Haight, T. G. (1998). A Primer on Quality Service, Quality Service Makes Happy Customers and Greater Profits. Business Forum, 23(3-4), 15-18.

Naumann, E., \& Giel, K. (1995). Customer Satisfaction Measurement and Management. Thomson Executive Press. 
Normann, R. (1991). Service Management: Strategy and Leadership in Service Business John Wiley and Sons.

O’Malley, \& Lisa. (1998). Can Loyalty Schemes Really Build Loyalty? Journal of Marketing Intelligence \& Planning, 16(1), 47-55. http://dx.doi.org/10.1108/02634509810199535

Ostrowsky, P. L., O’Brien, T. V., \& Gordon, G. L. (1993). Service Quality and Customer Satisfaction in the Commercial Airline Industry. Journal of Travel Research, 16-24. http://dx.doi.org/10.1177/004728759303200203

Owen, L., \& Othman, Q. A. (2002). Adopting and Measuring Customer Service Quality (SQ) in Islamic Banks: A Case Study in Kuwait Finance House. International Journal of Islamic Financial Service, 3(1).

Parasuraman, A., Zeithaml, V. A., \& Berry, L. L. (1985). Conceptual Model of Service Quality and Implication for Future Research. Journal of Marketing, 49, 41-50. http://dx.doi.org/10.2307/1251430

Parasuraman, A., Zeithaml, V. A., \& Berry, L. L. (1988). SERVQUAL: A Multi-Item Scale for Measuring Consumer Percepsions of Service Quality. Journal of Retailing, 65(1), 12-36.

Parasuraman, A., Zeithaml, V. A., \& Berry, L. L. (1993). The Nature and Determinants of Customer Expectations of Service. Journal of the Academy of Marketing Science, 21(1), 1-12. http://dx.doi.org/10.1177/0092070393211001

Parasuraman, A., Zeithaml, V. A., \& Berry, L. L. (1994). Reassessment of Expectations as a Comparison Standard in Measuring Service Quality: Implications for Further Research. Journal of Marketing, 58, 111-124. http://dx.doi.org/10.2307/1252255

Parasuraman. (1991). Understanding Customer Expextations of Service. Sloan Management Review, 32, 39-48.

Pardede, M. (2001). Effectiveness of Banking Supervision, In the National Banking Indonesia. Journal of Business Law, 15.

Parker, C., \& Brian, P. M. (2001). Customer Satisfaction: Contrasting Academic and Customer Interpretations. Journal of Marketing Intelligence \& Planning, 19(1), 38-44. http://dx.doi.org/10.1108/02634500110363790

Patterson, G. P., \& Spreng, A. R. (1997). Modelling Relationship between Perceived Value, Satisfaction and Repurchase Intentions in a Business-to-Business, Services Context: An Empirical Examination. International Journal of Service Industry Management, $8, \quad 414-134$. http://dx.doi.org/10.1108/09564239710189835

Patterson, G. P., Johnson, W. L., \& Spreng, A. R. (1997). Modelling the Determinants of Customer Satisfaction for Business-to-Business Professional Service. Academy of Marketing Science Journal, 25(1), 4-17. http://dx.doi.org/10.1007/BF02894505

Payne, A. (2001). The Essence of Service Marketing Andi, Yogyakarta.

Prabhu, S. (1996). Challenges for Hospitality and Tourism Operators: A North American Perspective. International Journal of Contemporary Hospitality Management, 8(7), 25-62. http://dx.doi.org/10.1108/09596119610152050

Ranaweera, C., \& Prabhu, J. (2003). On the Relative Importance of Customer Satisfaction and Trust as Determinants of Customer Retention and Positive Word of Mouth. Journal of Targeting, Measurement and Analysis for Marketing, 12(1), 82-90. http://dx.doi.org/10.1057/palgrave.jt.5740100

Rangkuty, F. (2002). Measuring Customer Satisfaction. Gramedia Pustaka Utama, Jakarta.

Ranupandojo, H., \& Dan Husnan, S. (1990). Personnel management BPFE. Universitas Gajah Mada, Jogjakarta.

Reichheld, F., \& Sasser, W. (1990). Zero Defections: Quality Comes to Services. Harvard Business Review, 68, 105-111.

Rindjin, K. (2003). Introduction to Banking and Financial Institutions Bank. Second printing Gramedia Pustaka Utama, Jakarta.

Robbins, S. P. (2001). Organizational Behavior: Concept, Controversies, Applications (9th ed.). New Jersey Prentice-Hall, Inc, A. Simon \& Schuster Company.

Roberts, J. (1993). Marketing for the Hospitality Industry. Hodder an Stoughton, Auckland.

Sabihaini. (2002). Analysis of Behavioral Consequences of Service Quality: An Empirical Research.

Sabol, S., Singh, J., \& Sirdeshmukh. (2002). Consumer Trust, Value and Loyalty in Relational Exchanges. Journal of Marketing, 66, 15-37. http://dx.doi.org/10.1509/jmkg.66.1.15.18449 
Sampara, L. (2000). Service Quality Management, College of Administrative Sciences-Institute of Administration (1st ed.). Jakarta: Negara Press.

Selnes, F. (1993). An Examination of the Effect of Product Performance on Brand Reputation, Satisfaction and Loyalty. European Journal of Marketing, 27(9), 19-35. http://dx.doi.org/10.1108/03090569310043179

Sirdeshmukh, D., \& Sinah, J. (2000). Agency and Trust Mechanisms in Consumer Satisfaction and Loyalty Judgments. Academy of Marketing Science Journal, 28(1), 150-167. http://dx.doi.org/10.1177/0092070300281014

Soderlund, M., \& Ohman, N. (2003). Behavioral Intentions in Satisfaction Research Revisited. Journal of Consumer Satisfaction, Dissatisfaction and Complaining Behavior, 16, 53-66.

Soeratno, D. L. A. (1995). Methods for Economics and Business Research. UPP AMP YKPN, Revised Edition, Second Matter Yogyakarta.

Storbacka, K., Strandvik, T., \& Gronroos, C. (1999). Managing Customer Relationships for Profit: The Dynamics of Relationship Quality. International Journal of Service Industry Management, 5(5), 21-38. http://dx.doi.org/10.1108/09564239410074358

Suryadi, A. (1991). Indicators of Quality and Efficiency of Primary Education in Indonesia. Research and Development Department of Education Jakarta.

Swan, J. E., Martin, W. S., \& Trawiek, F. I. (2003). Compensatory Satisfaction: An Ethnography of Avoiding Disappoinment And Producing Satisfaction In Birding. Journal of Consumer Satisfaction and Complaining Behavior, 16, 157.

Taylor, A. S., \& Hunter, G. (2003). An Exploratory Investigation Into the Antecedents of Satisfaction, Brand Attitude and Loyalty Within the (B2B) ECRM Industry. Journal of Consumer Satisfaction, Dissatisfaction and Complaining Bahavior, 16, 19-35.

Teas, K. R. (1993). Expectations, Performance Evaluation and Consumers' Perceptions of Quality. Journal of Marketing, 57, 18-34. http://dx.doi.org/10.2307/1252216

Thwaites, D. (1999). Closing the Gap: Service Quality in Sport Tourism. Journal of Services Marketing, 13(6), 500-516. http://dx.doi.org/10.1108/08876049910298766

Tjiptono, F. (1995). Marketing Strategy (2nd ed.). Andi Yogyakarta.

Voss, C., Chase, R. B., \& Roth, V. A. (1999). International Service Study (pp. 4-7). International Issues, College of Business Administration, University of South Carolina, Decision Line (May).

Walker, J. L. (1995). Service on Counter Satisfaction Conceptualised. Journal of Service Marketing, 9(1), 5-14. http://dx.doi.org/10.1108/08876049510079844

Wood. J., Wallace, J., Zeffane, R. M., Kennedy, D. J., Schermerhan, Z. R., Hunt, J. G., \& Osborn, R. N. (1998). Organizational Behavior: An Asia-Pacific Perspective.

Woodside, G. A. (1989). Linkking Service Quality, Customer Satisfaction and Behavioral Intention. Journal of Health Care Marketing, 9(4), 5-17.

Yoon, E., Guffery, H. J., \& Kijewski, V. (1993). The Effects of Information and Company Reputation on Intentions to Buy a Bussiness Service. Journal of Business Research, 27, 215-228. http://dx.doi.org/10.1016/0148-2963(93)90027-M

Zeithaml, V. A. (1996). The Behavioral Consequencies of Service Quality. Journal of Marketing, 60(2), 31-46. http://dx.doi.org/10.2307/1251929

Zeithaml, V. A. (1998). Consumer Perception of Price Quality and Value; A Means-End Model and Synthesis of Evidence. Journal of Marketing, 50(July), 2-22.

Zeithaml, V. A., \& Bitner, M. J. (1996). Services Marketing. McGraw-Hill: International Editions.

\section{Copyrights}

Copyright for this article is retained by the author(s), with first publication rights granted to the journal.

This is an open-access article distributed under the terms and conditions of the Creative Commons Attribution license (http://creativecommons.org/licenses/by/3.0/). 